\title{
Reinventing Hubungan Birokrasi dan Politik dalam Mewujudkan Hubungan Industrial yang Berkeadilan di Indonesia: Suatu Kajian
}

\author{
Wandi $^{*}$, Ahmad Rifa'i ${ }^{2}$ \\ ${ }^{1,2}$ Dosen Tetap Universitas Islam Indragiri - Tembilahan Propinsi Riau \\ *Correspondence email: wandi_sh68@yahoo.com \& 2 rifaisulasin@gmail.com
}

\begin{abstract}
Reinventing bureaucracy and politics must accommodate the tendency of bureaucratic political behavior. In short, public bureaucracy must be declared a political actor. As political actors, bureaucracy must not be neutral. He must increase the intensity of his involvement in the political process. However, the involvement of the public bureaucracy is not only oriented towards pursuing group profits solely. The involvement of bureaucracy in the political process and the bureaucracy's neutrality is the bureaucratic alignment of public interests such as economic progress, social justice, human rights, gender equality, and so on. Pancasila Industrial Relations as stated above can not be separated from the bureaucratic and political relations in a nation, therefore, it is important to do Reinventing Bureaucratic and Political Relations in realizing the democratization of industrial relations with justice in accordance with the values of Pancasila itself, namely by carrying out the Order Good governance.
\end{abstract}

Keywoords: Reinventing, Bureaucratic, Political, Relations, Industrial Relations

\section{Pendahuluan}

Maraknya demontrasi buruh di Indonesia dapat menimbulkan pemikiran tentang perlunya suatu sistem hukum perburuhan Indonesia yang berkeadilan. Penggunaan istilah hukum perburuhan dalam judul itu bukanlah suatu kesalahan atau kelalaian. Ada dua alasan pemilihan judul itu. Pertama, Departemen ruang lingkup hukum ketenagakerjaan adalah lebih luas daripada hukum perburuhan. Hukum perburuhan adalah hukum yang mengatur tentang hal-hal yang berkenaan dengan adanya hubungan kerja antara buruh/pekerja dengan majikan/pemberi kerja. Undang-undang Nomor 13 Tahun 2003 tentang Ketenagakerjaan yang selanjutnya disingkat UUK, mempersempit pengertian pemberi kerja hanya terbatas pada pengusaha saja. Antara aturan dan substansi UUK mengandung perbedaan. Seharusnya, apabila UUK dimaknai Ketenagakerjaan maka substansinya mengatur juga hubungan kerja yang dilakukan dalam lingkup informal, hubungan hukum antara negara dengan pegawainya dan militer.(Wijayanti, 2012)

Untuk mewujudkan Indonesia sebagai negara hukum, negara berkewajiban melaksanakan pembangunan hukum nasional yang dilakukan secara terencana, terpadu, dan berkelanjutan dalam sistem hukum nasional yang menjamin pelindungan hak dan kewajiban segenap rakyat Indonesia berdasarkan Undang-Undang Dasar Negara Republik Indonesia Tahun 1945. UU No. 12 Tahun 2011 menyatakan bahwa pembentukan pembentukan peraturan perundang-undangan merupakan salah satu syarat dalam rangka pembangunan hukum nasional yang hanya dapat terwujud apabila didukung oleh cara dan metode yang pasti, baku, dan standar yang mengikat semua lembaga yang berwenang, tentunya tidak lepas dari keterkaitan antara birokrasi dan politik suatu negara. Birokrasi dan politik sebagai dua institusi yang berbeda namun sulit untuk dipisahkan. Keduannya saling memberikan kontribusi bagi pelaksanaan pemerintahan baik pada level pemerintah pusat maupun daerah yang baik. Institusi politik dan birokrasi melakukan proses chek and balance agar senantiasa berada dalam koridor esensi otonomi dalam melaksanakan kebijakan. Interaksi antara kedua institusi tersebut melahirkan pola relasi yang dinamis konstruktif, namun disisi lain menampakan fenomena sebaliknya, yaitu adanya perselingkuhan yang meminggirkan kepentingan publik.

Sebagaimana dikemukakan di atas bahwa institusi politik dan birokrasi merupakan institusi yang berbeda karakternya. Birokrasi sebagai suatu sistem organisasi formal dimunculkan pertama sekali oleh Max Weber (1947), menurutnya, birokrasi merupakan tipe ideal bagi semua organisasi formal. Ciri organisasi yang mengikuti sistem birokrasi adalah pembagian kerja dan spesialisasi, orientasi impersonal, kekuasaan hirarkis, peraturan-peraturan, karir yang panjang, dan efisiensi. Sedangkan institusi politik berkarakter demokrasi yang ditandai oleh adanya kebebasan sipil dan politik, seperti kebebasan berbicara, menulis, berkumpul dan berorganisasi, dan perdebatanperdebatan politik. Sebagai individu manusia tidak akan bisa hidup dan berkembang berdasarkan kemampuan dirinya semata. Manusia membutuhkan lembaga sosial, memerlukan masyarakat dan Negara. Manusia membutuhkan sistem nilai, ideology, yang menjadi tujuan dan pedoman hidupnya sebagai warga Negara dari suatu masyarakat. Sebaliknya proses hidupnya sebagai pribadi ikut memberikan bentuk lembaga sosial, sistem nilai dan ideology masyarakat yang bersangkutan. Dengan demikian, manusia sebagai mahluk sosial juga menghadapi kehidupan politik. (Hermawan, 2011).

Dalam konteks ini, manusia mau tidak mau harus berinteraksi dengan kekuasaan yang menentukan gerak hidup masyarakat sebagai kesatuan. Dalam rangka itu kekuasaan merupakan sarana untuk membereskan berbagai 
persoalan yang terjadi dalam hubungan antar pribadi, antar kelompok atau warga Negara berdasarkan peraturan yang adil dan pasti (Manan, 2001). Oleh karena itu, meski kadang dunia politik dipandang sinis atau kotor tetapi secara filosofis dan factual, politik merupakan hal yang tidak mungkin dipisahkan dari kehidupan manusia. Aristoteles pada Tahun 384-322 SM pernah menyatakan bahwa man is by nature an political animal. Hukum adalah produk politik. Hukum tidak steril dan netral dari politik. Ada beberapa pendapat yang mengatakan esensi politik adalah konflik. Hal ini karena politik adalah hal mencari, mempertahankan dan memanfaatkan kekuasaan. (Hermawan, 2002). Politik yang identik dengan konflik dalam pemerintahan suatu Negara. Salah satu kenyataan dasar dari kehidupan manusia ini bahwa orang hidup bersama-sama tidak dalam isolasi satu sama lainnya. Para sosiolog pada umumnya mengatakan bahwa kelompok manusia yang hidup bersama-sama tersebut dalam bentuk yang besar disebut masyarakat ( $a$ society). Secara teoritis, dinamika konflik termasuk konflik ketenagakerjaan dapat dipaparkan, bahwa jika wujud konflik masih dalam kadar relatif rendah dan masih dapat ditolelir, penyelesaiannya tidak sulit. Namun jika konflik sudah mencapai tingkat yang relative gawat sehingga sulit dikendalikan, maka konflik dapat menimbulkan kekerasan bahkan dapat terjadi disintegrasi. (Yanto, 1991). Di dalam fenomena konflik terdapat aktaulisasi isu sentral masalah yang dipertentangkan. Konflik mempunyai akar persoalan yang bersumber dari factor internal dan eksternal, sehingga konflik dapat terjadi secara cepat. Berdasarkan konsep analisis siklus konflik Kreisberg konflik terjadi mulai dari tahap awal, selanjutnya meningkat hingga mencapai tingkat tinggi hingga mengalami penurunan dan berakhir. Berakhirnya konflik dapat membuahkan konflik berhenti sama sekali atau hasilnya justru berupa sesuatu yang menjadi penyebab munculnya konflik baru. (Kreiberg, 1982)

Manusia berkepentingan merasa aman dan mengharapkan kepentingannya di lindungi terhadap konflik. Gangguan kepentingan atau konflik harus dicegah dan diselesaikan karena akan menggangu keseimbangan tatanan masyarakat. Hukum berusaha menampung ketegangan atau konflik sebaik-baiknya, hanya saja dalam masyarakat kapitalis yang dikuasai oleh kaum borjuis, hukum itu adalah ideologi kaum borjuis tersebut. Dalam masyarakat kapitalis maka hukum itu suatu tata tertib tertentu yang member kemungkinan melanjutkan pertentangan antara golongan yang menguasai alat-alat produksi (borjuis) dengan golongan yang tidak menguasai alat-alat produksi (proletar). (Utreecht, 1966). Hukum menjadi ideologi karena pembuat hukum sudah apriori dalam arti sebelum membuat peraturan hukum yang bersangkuta, sudah memiliki konsepsi apriori tentang bagaimana seharusnya peraturan hukum tersebut. Pembuat peraturan berusaha merealisasikan konsepsi tersebut bahkan juga dalam konsepsi tidak sesuai dengan hubungan-hubungan ekonomis yang sungguh-sungguh ada dalam masyarakat. Hukum tidak lain daripa kehendak suatu "ruling class" yang tidak memperhatikan kepentingan ekonomis yang di perintahnya. Sejarah dunia penuh dengan kisah pengorbanan manusia tertindas yang ingin meraih kemerdekaan dan kebebasan baik dari kekuatan represif asing maupun domestik. Tetapi pengalaman di berbagai negara menunjukan, bahwa kebebasan dan demokrasi bersifat fragil, rawan terhadap kemungkinan penyelewengan. Disamping selalu ada arus tuntutan kepada demokrasidan kebebasan, selalu ada pula arus balik yang cenderung membatasinya. Demokrasi biasanya disuarakan secara lantang oleh mereka yang berada di luar kekuasaan, dan pembatasan terhadap pelaksanaan demokrasi umumnya dilakukan oleh pemegang kekuasaan. Banyak orang menggunakan demokrasi dan kebebasan sebagai instrumen untuk tujuan lain diluar demokrasi, atau untuk mencapai kekuasaan, bukan untuk nilai politik yang harus dijunjung tinggi atau sebagai aturan main yang harus diikuti secara konsisten dalam situasi apapun. Banyak pula penguasa otoriter yang mengesyahkan kekuasaan dengan simbol-simbol demokrasi yang semu, karena mereka tahu bahwa otoritarianisme bukanlah ideologi politik yang populer dimata rakyat dan dunia Internasional. Banyak contoh pergolakan rakyat untuk membebaskan diri dari belenggu penjajah yang justru melahirkan pemerintahan negara merdeka yang jauh lebih kejam dari pada penjajah itu sendiri. Banyak pula contoh revolusi untuk menumbangkan pemerintah yang represif justru melahirkan bentuk pemerintahan yang lebih diktaktor dan kejam dari rezim lama yang telah ditumbangkan.

Salah satu faktor penting yang ikut andil dalam pengembangan demokrasi adalah birokrasi artinya, birokrasi dapat memainkan peranan penting baik yang sifatnya positip maupun negatif. Demokrasi agar efektif, memerlukan dukungan birokrasi, antara lain dengan mengimplementasikan kebijakan-kebijakan publik secara efektif, dan sebagai instrumen untuk menjaga tertip sosial. Birokrasi yang lemah, dapat membawa demokrasi kedalam chaos, yang pada gilirannya akan merusak masa depan demokrasi itu sendiri. Sebaliknya birokrasi yang terlalu kuat dapat melumpuhkan pelaksanaan fungsi lembaga-lembaga politik lain, sehingga proses check and balance tidak dapat berlangsung dengan baik. Birokrasi yang terlau kuat, juga membuat rakyat terlalu tergantung kepadanya, sehingga inisiatif rakyat tidak dapat berkembang. Ringkasanya birokrasi yang terlalu kuat bisa mengancam sendi-sendi demokrasi. Secara harfiah demokrasi berasal dari bahasa latin demokratia. (Dari akar kata "demos" yang berarti rakyat dan "kratia" berarti pemerintahan ). Demokrasi dengan demikian berarti pemerintahan kerakyatan, dalam sistem ini pemegang kekuasaan harus bertanggung jawab pada rakyat dan memerintah atasnamanya. Kekuasaanpun diperoleh melalui kompetisi atau sistem pemilihan yang bebas dan terbuka. Karena itu pula setiap orang memiliki hak dan kesempatan yang sama untuk memperoleh kekuasaan secara demokratis. Penguasa yang demokratis akan memandang kritik sosial sebagai bagian 
dari mekanisme politik, dan tidak akan menggunakan kekuasaanya untuk menekan kritik sosial karena sebagai bagian dari sistem politik, dan tidak akan menggunakan kekuasaannya untuk menekan kritik sosial. Pergantian kekuasaan umumnya didiskusikan secara terbuka menjadi bagian dari diskusi publik dan berlangsung secara normal mengikuti aturan yang diterima.

Oleh karena adanya konflik kepentingan sebagaimana yang telah diuraikan di atas maka penulis dalam melakukan penulisan makalah ini bermaksud untuk memberikan sumbangsih pemikiran atas kepentingan masingmasing entitas tersebut dengan mengkaitkan peran birokrasi yang baik (Good Governance) dalam membangun demokratisasi Hubungan Industrial yang berkeadilan di Indonesia, tentunya untuk membangun birokrasi yang baik tersebut tidak terlepas dari dinamika politik yang berkembang pada saat ini. Tujuan penelitian adalah untuk mengkaji bagaimanakah reiventing birokrasi dan politik dalam mewujudkan demokratisasi hubungan industrial yang berkeadilan di Indonesia"

\section{Konsep Teori}

Konsep teori yang digunakan dalam menganalisis Konsep Reiventing Birokrasi dan Politik yang baik guna mewujudkan demokratisasi Hubungan Industrial yang berkeadilan di Indonesia adalah Teori Reinventing government, hal ini penulis lakukan dengan alasan bahwa Reinventing government merupakan cara birokrasi mengubah sistem atau pengaturan agar pelaksanaan pemeritahan dapat berjalan secara akuntabilitas, resposif, inovatif, professional, dan entrepreneur. Entrepreneur dimaksudkan agar pemerintah yang telah diberikan mandate oleh rakyat memiliki semangat untuk lebih inovatif dalam memberikan pelayanan kepada masyarakat khususnya pekerja dan dapat menjawab tuntutan masyarakat pencari kerja di era globalisasi. Sehingga mewirausahakan birokrasi bukan berarti birokrasi melakukan wirausaha untuk mendapatkan keuntungan yang sebesar-besarnya melainkan memberdayakan institusi agar produktivitas dan efisiensi kerja dapat dioptimalkan.

\section{Pembahasan}

\section{Konsep Reinventing Hubungan Birokrasi dan Politik Di Indonesia}

Hubungan antara birokrasi dan politik telah menjadi tema klasik dalam studi administrasi publik. Dimana muncul konsep Dikotomi antara Politik dengan Administrasi oleh Woodrow Wilson. Ia menjelaskan bahwa politik dan administrasi berada di dua posisi yang berbeda. Politik menyangkut bagaimana membuat kebijakan publik sedangkan administrasi berkaitan dengan implementasi kebijakan publik. Perjalanan administrasi publik tidak terlepas dengan perkembangan ilmu politik. Dalam Paradigma Ilmu administrasi antara tahun 1900-1926 terjadi dikotomi Politik dan Administrasi, namun pada tahun 1950-1970 Administrasi Negara masuk sebagai ilmu politik. Namun setelah era tersebut sekitar tahun 1970-an sampai sekarang administrasi negara berdiri sendiri sebagai ilmu pengetahuan. Oleh karena itu ilmu politik menjadi bagian tak terpisahkan dari ilmu administrasi Negara. Kajian birokrasi dan politik, mengingatkan kembali antar hubungan masa lalu antara ilmu administrasi Negara dengan ilmu politik. Kedua disiplin ilmu tersebut memilki ranah yang berbeda, namun dalam prakteknya kedua ilmu tersebut sulit untuk dibedakan. Terkadang keduanya saling mendukumg bahkan saling menghambat satu sama lain. Melihat kondisi saat ini dinamika antara birokrasi dan politik sangatlah pelik. Namun kombinasi keduanya jika ditempatkan dalam posisi yang tepat masih memiliki kesempatan untuk menuju good governance.

Birokrasi pemerintah tidak bisa dilepaskan dari proses dan kegiatan politik sebagaimana yang telah dikemukakan di atas, hal ini menunjukkan pada setiap gugusan masyarakat yang membentuk suatu tata kepemerintahan tidak bisa dilepaskan dari aspek politik. Politik sebagaimana kita ketahui bersama terdiri dari orangorang yang berperilaku dan bertindak politik (consists of people acting politically) yang diorganisasikan secara politik oleh kelompok-kelompok kepentingan dan berusaha mencoba mempengaruhi pemerintah untuk mengambil dan melaksanakan suatu kebijakan dan tindakan yang bisa mengangkat kepentingannya dan menyampingkan kepentingan kelompok-kelompok lainnya. Kelompok masyarakat itu mempunyai kepentingan yang diperjuangkan agar pemerintah terpengaruh. Birokrasi pemerintah langsung atau tidak langsung akan selalu berhubungan dengan kelompok-kelompok kepentingan dalam masyarakat (Toha, 2014). Penguasa pemerintah di hampir setiap Negara percaya bahwa tugas utama dari setiap pemerintahan apakah demokratis atau otoritarian adalah untuk menjamin agar Negara dan bangsanya tetap hidup dan Berjaya. Kejayaan dan kehidupan suatu Negara mencakup dua tugas fundamental yang harus tetap dijalankan. Dua tugas fundamental itu antara lain; mempertahankan kemerdekaannya dari ancaman musuh dari luar, dan kedua mengendalikan dan mengelola konflik internal agar tidak berlarut-larut menjadi perang saudara.

Untuk mencapai tugas fundamental kedua tersebut pemerintah harus bisa memuaskan kebutuhan rakyat yang nantinya bisa menerima dan mendukung kebijakan dan program-program pemerintah. Pemerintah mendengar, mengamati, dan menyaring melalui tuntutan-tuntutan politik yang secara ajeg dituntut oleh berbagai macam kelompok kepentingan. Tuntutan-tuntutan itu bisa berupa selalu melihat salah dan kekurangan pemerintah, mulai dari kesalahan kebijakan yang diambil sampai kepada realisasi kegiatan dan pengawasan. Kelompok-kelompok kepentingan tersebut 
menuntut dan bahkan memaksa agar pemerintah mengambil langkah-langkah kebijakan sesuai dengan tuntutannya. Jika tuntutan-tuntutan itu tidak di penuhi, mereka tidak puas dan dari sinilah bibit konflik internal di mulai. Dalam konteks hubungan industrial akhir-akhir ini pemerintah tengah mendapat soroton dari rakyat terutama dari kalangan pekerja dan akademisi berkaitan dengan isu omnibus law di bidang cipta kerja. Sistem Omnibus Law sendiri biasanya lazim dipakai di negara-negara dengan sistem hukumnya common law, sementara Indonesia menganut sistem hukum civil law. Padahal, sistem yang terus didorong pemerintah ini justru mulai dijauhi oleh banyak negara. Banyak negara justru kapok dengan proses pembuatan Omnibus Law karena jauh dari proses demokrasi yang deliberatif atau deliberative democracy. Bahkan mereka menyebut model omnibus ini undemocratic atau tidak demokratis.

Dalam khazanah pemikiran klasik, seperti terungkap dalam pemikiran Woodrow Wilson (1887) yang tertuang dalam paper The Study of Administration, politik dan birokrasi (sebagai institusi yang mewakili dunia administrasi) adalah dua hal yang berbeda, terpisah, dan dominatif. Bagi Woodrow Wilson, politik adalah urusan formulasi kebijakan yang menjadi hak para politisi yang dipilih melalui pemilihan umum. Sementara itu, administrasi adalah persoalan bagaimana mengimplementasikan kebijakan yang dibuat para politisi secara efektif dan efisien (Wilson, 1887). Sejarah mencatat bahwa pemikiran ini sangat mempengaruhi perkembangan pemikiran generasi ilmuwan administrasi publik pasca Wilson. White (1926), misalnya, dengan sangat berani mengungkapkan bahwa administrasi terkait dengan masalah bagaimana memanajem orang-orang dan barang-barang material untuk mencapai tujuan tertentu dengan tegas mengatakan bahwa Strategi Reposisi-Reposisi birokrasi publik merupakan satu keniscayaan politik. Masalahnya, bagaimana menjalankan reposisi yang bertolak dari asumsi bahwa politik merupakan bagian terpenting dalam kegiatan birokrasi publik sehari-hari. Secara teoritik tidak ada kata sepakat di antara ilmuwan administrasi publik tentang teori reformasi birokrasi yang komprehensif dan holistik. Mosher (1975) misalnya, mengajukan argumen bahwa reformasi birokrasi publik harus ditekankan kepada 4 (empat) dimensi: (1) reformasi pada level program dan kebijakan publik; (2) perbaikan kualitas efektivitas roda administrasi yang meliputi perluasan kontrol atasan terhadap bawahan dalam rangka perbaikan koordinasi, desentralisasi proses pengambilan keputusan, peningkatan produktivitas, efisiensi, dan efektivitas, dan pendalaman penggunaan prinsip-prinsip administrasi modern; (3) reformasi kepegawaian birokrasi publik yang meliputi analisa tentang kualifikasi, kesejahteraan, kepuasaan kerja pegawai birokrasi publik; (4) dimensi yang menjadi fokus kritik aktor-aktor di luar birokrasi publik. Sementara itu, Paul Appleby membedakan strategi reformasi birokrasi publik menjadi dua jenis, yakni: reformasi incremental dan episodic. Reformasi inkremental dimaknai sebagai modifikasi terus menerus terhadap aktivitas keseharian birokrasi publik. Termasuk dalam kategori ini penyusunan sistem karir birokrasi, perbaikan anggaran birokrasi, penilaian kinerja, dan sebagainya. Sedang reformasi episodic merujuk pada upaya perubahan struktur dan proses birokrasi publik yang dilakukan dalam kurun waktu tertentu dan meliputi keseluruhan aspek birokrasi publik. Dibandingkan dengan reformasi inkremental, tipe strategi reformasi ini lebih terencana, holistik, dan memiliki orientasi jangka panjang. Strategi incremental lebih merupakan proses penyesuaian (adjustment) sementara strategi episodic merupakan reorganisasi/reformasi birokrasi publik yang sesungguhnya.

Bertolak dari asumsi bahwa politik dan administrasi merupakan dua dunia yang dapat dibedakan tetapi tetapi tak dapat dipisahkan satu dengan yang lainnya, maka dalam peneulisan makalah ini penulis mengajukan grand scenario dengan melakukan Reinventing Birokrasi dan politik dalam dua bentuk, yaitu: Pertama, Reinventing Birokrasi dan Politik dalam ranah politik (political sphere); Sistem politik lokal dibangun atas dasar keterkaitan dan ketergantungan antar lembaga di ranah government dan non-government. Konsekuensinya, sistem politik di tingkat lokal harus memberikan peluang seluas-luasnya kepada aktor non- state untuk terlibat dalam proses pengambilan keputusan politik. Harus ada mekanisme politik di tingkat lokal yang jelas, absah, dan mengakui kehadiran aktor politik non-state. Agar tidak terjebak dalam permainan politik elitis, setiap proses politik harus bersifat terbuka untuk umum sehingga transparansi proses pengambilan keputusan politik bisa tercapai. Masalah-masalah publik, seperti kemiskinan, pengangguran, dan ketimpangan, harus dijadikan prioritas kebijakan politik di tingkat lokal dan dituangkan melalui keputusan politik tersendiri yang berbeda dengan prioritas kebijakan sekunder. Dalam banyak kasus, isu kebijakan yang menyentuh kepentingan rakyat banyak seringkali terabaikan akibat rancangan prioritas kebijakan elit politik yang lebih menyukai program-program pembangunan yang memungkinkan mereka menumpuk keuntungan ekonomi dari program-program pembangunan. Pada tataran praktis, Reinventing birokrasi dan politik dapat dimulai dari penerapan pemilihan kepala daerah (pilkada) secara langsung, Jika 'bos' eksekutif dipilih secara langsung, maka kecenderungan birokrasi untuk melayani kepentingan politik eksekutif dan legislatif menjadi berkurang. Pemilihan kepala daerah secara langsung akan semakin mendekatkan jarak politik antara pihak eksekutif, legislatif, birokrasi dengan konstituen mereka. Kondisi ini diharapkan dapat memicu lahirnya keputusan-keputusan politik yang lebih berpihak kepada kepentingan rakyat banyak. Sebab, secara teoritik, jika sosok kepala daerah tidak familiar dengan kepentingan politik mayoritas massa pemilih maka karir politik mereka bisa terancam. Kecenderungan para politisi untuk mempertahankan kekuasaan politik mereka menjadi sah-sah saja ketika ia selalu berorientasi kepada kepentingan politik rakyat di tingkat grass root. Dan hal ini hanya bisa terjadi jika massa rakyat 
terlibat langsung dalam proses pemilihan kepala daerah. Kedua, Reinventing birokrasi dan politik harus mengakomodir kecenderungan perilaku politik birokrasi. Singkat kata, birokrasi publik harus dinyatakan sebagai aktor politik. Sebagai aktor politik, birokrasi tidak boleh netral. la harus meningkatkan intensitas keterlibatannya dalam proses politik. Tetapi, keterlibatan birokrasi publik itu tidak hanya diorientasikan untuk mengejar keuntungan kelompok semata-mata. Keterlibatan birokrasi dalam proses politik dan ketidaknetralan birokrasi adalah keberpihakan birokrasi terhadap kepentingan publik seperti kemajuan ekonomi, keadilan sosial, hak asasi manusia, kesetaraan gender, dan sebagainya. Dalam konteks ini birokrasi publik merupakan salah satu instrumen efektif dalam proses redemokratisasi proses politik di tingkat lokal. Meskipun, karakteristik birokrasi publik seringkali dianggap bertolak belakang dengan demokrasi, baik dilihat secara prosedural maupun substantif. Tetapi, kita tidak boleh menutup mata bahwa birokrasi memiliki potensi sebagai kekuatan pro- demokrasi.

\section{Reinventing Hubungan Birokrasi dan Politik Dalam Mewujudkan Demokratisasi Hubungan Industrial yang berkeadilan di Indonesia}

Istilah birokrasi, kekuasaan, dan politik dalam dinamika pemerintahan Indonesia bagaikan kesatuan yang tidak terpisahkan. Hubungan ketiganya dapat dilacak dari sejarah awal pembentukan negara ini, dari masa kerajaan, zaman kolonial hingga setelah kemerdekaan. Tarik-menarik politik dan kekuasaan berpengaruh kuat terhadap pergeseran fungsi dan peran birokrasi selama ini. Birokrasi yang seharusnya bekerja melayani dan berpihak kepada rakyat berkembang menjadi melayani penguasa dengan keberpihakan pada politik dan kekuasaan. Sampai saat ini, pengaruh kuat pemerintah terhadap birokrasi membuat sulitnya mesin birokrasi memberi pelayanan publik yang profesional, rentan terhadap tarik-menarik kepentingan politik, korupsi, kolusi, nepotisme, inefisiensi, dan berbagai penyakit birokrasi lainnya (Wakhid, 2012). Sementara itu, masyarakat selama ini masih berpandangan bahwa birokrasi (administrasi negara) sama dengan pemerintah. Padahal keduanya berbeda dan tidak dapat disamakan. Untuk konteks Indonesia, pembedaan birokrasi (administrasi negara) dengan pemerintah, memang kurang lazim didengar. Kekeliruan itu membuat peran eksekutif tetap dominan dan berkuasa penuh atas birokrasi beserta sayap-sayapnya yang menjangkau seluruh lembaga-lembaga negara.

Dalam demokratisasi Hubungan Industrial di Indonesia, pemerintah bertugas untuk menjaga agar tujuan negara berjalan sesuai yang diamanatkan oleh Konstitusi negara Indonesia. Peran pemerintah diperlukan untuk menjaga keseimbangan antara para pemangku kepentingan terkait informasi, yaitu masyarakat, pemerintah, pengusaha dan pekerja. Pihak Pengusaha meliputi pengusaha sektor informal maupun sektor informal. Kewenangan Negara dijalankan oleh pejabat pemerintah (eksekutif). Mandat yang diberikan rakyat kepada negara meliputi perbuatan: 1) pembuatan kebijakan; 2) tindakan pengurusan; 3) Pengaturan; 4) Pengelolaan; 5) Pengawasan.

Sesuai dengan perkembangan konsep menjalankan pemerintahan, maka berkaitan dengan fungsi negara untuk menjaga ketertiban, memberikan kemakmuran dan memberikan layanan kepada masyarakat khususnya pelaku hubungan industrial (Pemerintah, Pengusaha dan Pekerja/Buruh), maka ketersediaan regulasi dan aturan hukum dalam bidang Hukum Ketenagakerjaan beserta bagaimana pemerintah bertindak sebagai pelaksana pengendalian hubungan industrial itu sendiri, pada akhirnya memerlukan suatu cara pandang baru agar masyarakat turut dilibatkan dalam penciptaan hubungan industrial yang memberikan rasa keadilan bagi para pihak. Pada masa Orde Baru, pemerintah bertindak sebagai pihak yang paling tahu tentang hubungan industrial, yang selanjutnya diimplementasikan dalam tindakan-tindakan pemerintah untuk mengontrol kebijakan-kebijakan di bidang ketenagakerjaan dengan dalih menjaga hubungan industrial pancasila. Pada perkembangannya, masyarakat tidak lagi dapat diperlakukan lagi sebagai pihak yang dianggap tidak tahu. Pemerintah sendiri tidak lagi dapat bertindak sebagai pemerintahan yang otoritarian. Sebuah sistem sosial bagaimanapun harus berubah sesuai dengan perkembangan masyarakatnya, demikian juga Pemerintahan Indonesia. Paradigma baru kemudian disosialisasikan bahwa pemerintah harus berubah dalam mencapai tujuan Negara. Dalam kondisi politik, menekankan tingkat kebebasan yang ada untuk pembentuk kelompok dan tindakan kelompok. Sementara itu, kondisi sosial terutama meliputi tingkat komunikasi antar anggota dari suatu kelompok. Kelompok-kelompok konflik pasti akan muncul diantara orang-orang terpencil satu sama lain yang secara ekologis sangat terpencar-pencar atau tidak mampu atau tidak bersedia karena alasan apapun untuk membentuk ikatan sosial. Kondisi-kondisi tersebut merupakan prasyarat dasar untuk pembentukan kelompok-kelompok konflik. Disamping itu perlu disadari bahwa kekuasaan keberadaannya adalah terbatas dan dapat dikatakan merupakan sesuatu yang langka dalam kehidupan bermasyarakat dan bernegara. Hal ini digambarkan oleh Mac Iver bahwa kekuasaan dalam masyarakat selalu berbentuk piramida (Budiardjo, 2000)

Di satu sisi bagi pemegang kekuasaan, kekuasaan biasanya mempunyai kecendrungan bersifat monopoli dan berusaha melanggengkannya. Masalah ini identik dengan hukum besi oligarki sebagaimana yang dikemukakan oleh Robert Michels, yang menyatakan bahwa ada kencendrungan umum bagi kekuasaan untuk menjadi terkonsentrasi pada tangan satu elit yang keputusan dan tindakannya secara bertahap diarahkan untuk mempertahankan kekuasaan dari pada meningkatkan kepentingan rakyatnya (Johnson, 1994). Indonesia sebagai Negara yang demokratis tentunya 
tidak lepas dari nilai-nilai pancasila yang hidup ditengah masyarakat yang telah diakui kebenarannya dan dijadikan pedoman dalam aktifitas masyarakatnya sehari-hari. Nilai-nilai bangsa tersebut tercantum dalam falsafah pancasila sehingga diharapkan dapat berkembang disetiap aspek kehidupan rakyat, begitupula dengan hubungan industrial di Indonesia diharapkan dapat berkembang dalam tiap-tiap perusahaan sesuai kepribadian bangsa berdasarkan pancasila. Hubungan industrial pancasila yang ada di Indonesia merupakan suatu hubungan industry menjadi ciri khas yang menjadi pembeda dengan Negara lain.

Rumimpunu (2014) menjelaskan hubungan industrial berlandaskan nilai-nilai pencasila yaitu; 1. Sila Pertama, sebagai landasan spiritual hubungan industrial, dalam bekerja manusia tidak hanya mencari nafkah tetapi mengabdi kepada tuhan dan sesame manusia, 2. Sila kedua, sebagai landasan kemanusian dengan menganggap pekerja bukan sekedar factor produksi tetapi sebagai mitra perusahaan, 3. Sila ketiga sebagai dasar kesatuan yang diterapkan berpedoman kepada tridharma yang mengandung asas partnership dan tanggung jawab bersama antara pekerja, manajemen, dan serika pekerja sehingga tercipta saling merasa ikut memiliki, memelihara, mempertahankan, dan terus menerus mawas diri, 4. Sila keempat, sebagai landasan demokrasi, semua pihak dalam proses produksi memiliki hak mengeluarkan pendapat yang sama sehingga selalu mengutamakan musyawarah mufakat dalam setiap pengambilan keputusan, 5. Sila kelima, sebagai landasan perwujudan keadilan sosial dengan menerapkan prinsip keadilan dalam lingkungan kerja di segala aspeknya dengan menghindari kesewenangan manajamen terhadap pekerja sebagai pihak yang lemah. Dalam mewujudkan Hubungan Industrial Pancasila sebagaimana yang telah dikemukakan di atas tidak terlepas dari hubungan birokrasi dan politik dalam suatu bangsa oleh karena itu penting dilakukan Reinventing Hubungan Birokrasi dan Politik dalam mewujudkan demokratisasi hubungan industrial yang berkeadilan sesuai dengan nilai-nilai pancasila itu sendiri yaitu dengan melakukan Tata Kepemerintahan yang baik (Good Governance) merupakan suatu konsep yang akhir-akhir ini dipergunakan secara reguler dalam ilmu politik dan administrasi publik. Konsep ini lahir sejalan dengan konsep-konsep dan terminologi demokrasi, masyarakat sipil, partisipasi rakyat, hak asasi manusia, dan pembangunan masyarakat secara berkelanjutan. Pada akhir dasa warsa yang lalu konsep good governance ini lebih dekat dipergunakan dalam reformasi sektor publik. Di dalam disiplin atau profesi manajemen publik konsep ini dipandang sebagai suatu aspek dalam paradigm baru ilmu administrasi publik. paradigma baru ini menekan pada peranan manajer publik agar memberikan pelayanan yang berkualitas kepada masyarakat, mendorong meningkatkan otonomi manajerial terutama sekali mengurangi campur tangan kontrol yang dilakukan oleh pemerintah, tansparansi, akuntabilitas publik, dan diciptakan pengelolaan manajerial yang bersih dari korupsi.

Tata kepemerintahan yang baik merupakan suatu kondisi yang menjamin adanya proses kesejajaran, kesamaan, kohesi dan keseimbangan peran serta adanya saling mengontrol yang dilakukan oleh pemerintah (government), rakyat (citizen) atau civil society, dan usahawan (business)/ pengusaha yang berada pada sektor swasta. Ketiga komponen ini mempunyai hubungan yang sama dan sederajat. Kesamaan derajat ini akan berpengaruh terhadap upaya menciptakan tata kepemerintahan yang baik dalam mendorong demokratisasi hubungan industrial itu sendiri. Upaya untuk menyeimbangkan ketiga komponen tersebut merupakan peranan yang harus dimainkan oleh para elit pemangku kekuasaan itu sendiri (politik) dalam mengorganisir dan melaksanakan aturan-aturan yang telah ditetapkan. Hal mana di karenakan Politik berurusan dengan pengambilan kebijakan, sementara administrasi berurusan dengan implementasi kebijakan. Sebagai lembaga implementasi, sistem dan prosedur birokrasi harus dikembangkan secara efisien, antara lain dengan struktur birokrasi yang hirarkhis, aturan-aturan yang berlaku secara impersonal, juga sistem pengembangan karier yang dapat menjamin perkembangan profesional aparaturnya. Tujuan dari pengembangan konsep ini adalah untuk menjamin efektivitas pemerintahan yang telah berkembang secara demokratis. Artinya mekanisme politik yang demokratis harus ditopang oleh birokrasi yang profesional agar semua kebijakan politik khususnya yang berkaitan dengan pengaturan hubungan industrial yang akan diputusakan dapat diimplementasikan secara lebih efisien. Pengembangan birokrasi yang rasional pada akhirnya dapat menimbulkan proses birokratisasi, yaitu menguatnya peranan politik birokrasi dalam sistem pemerintahan yang pada gilirannya telah mengurangi kadar demokrasi dan sistem politik. Meskipun birokrasi resminya merupakan lembaga implementasi, tetapi sesungguhnya para aparaturnya memiliki diskresi yang tinggi dalam pembuatan kebijakan-kebijakan publik.

Birokrasi menjadi salah satu dari segitiga di samping politisi dan kelompok kepentingan yang mempunyai peranan kunci dalam mekanisme politik (long, 1986). Oleh karena itu, negara-negara modern saat ini sering disindir dengan julukan yang bersifat derogatif sepertiadminstrative state (Waldo, 1948) bureaucratic state (Gerald, 1982) atau government of the bureaucrats, by the bureaucrats, for the bureaucrats. Hal demikian dimungkinkan karena birokrasi dilengkapi dengan sumberdaya yang tidak dimiliki oleh lembaga-lembaga politik lainnya. Ia menguasai informasi, yang diperlukan, dalam pengambilan kebijakan publik, ia bisa berkolaborasi dengan intelektual untuk merumuskan kebijakan secara tehnokratis, sumber dana, dan lain-lain. Dengan sumber daya yang dimiliki dan dikuasai birokrasi dapat melakukan mobilisasi dukungan politik secara efektif terhadap langkah-langkah strategis yang diambil dalam membangun hubungan industrial yang berkeadilan. Kehadiran Reinventing Hubungan Birokrasi dan Politik sangat diperlukan bagi tegaknya sebuah negara yang berdaulat. Pengembangan demokrasi tidak boleh 
tidak memerlukan keterlibatan birokrasi, karena birokrat dapat melakukan hal-hal yang tidak dapat dilakukan oleh politisi. Kadang-kadang birokrasi modern cenderung berkembang mengikuti wataknya sendiri yang secara fundamental berlawanan dengan karakter demokrasi. Secara ringkas dapat dikatakan bahwa demokrasi bercirikan populis, sementara birokrasi mempunyai ciri-ciri hirarkis. Nilai yang dominan dalam demokrasi adalah keadilan, sementara untuk birokrasi nilai yang dominan adalah efektif dan efisien. Demokrasi ditegakan atas dasar nilai kesamaan (equity) dan persamaan hak, dan pengambilan keputusan bersifat partisipatory keputusan atau kebijakan yang diambil politisi merupakan melaksanakan kehendak rakyat, dan politisi harus mempertanggung jawabkan semua kebijakan yang diambil kepada rakyat dari mana kekuasaan mereka berasal. Sebaliknya birokrasi ditegakan atas dasar perbedaan status dan peranan (spesialisasi dan hirarkis).

\section{Simpulan}

Reinventing birokrasi dan politik harus mengakomodir kecenderungan perilaku politik birokrasi. Singkat kata, birokrasi publik harus dinyatakan sebagai aktor politik. Sebagai aktor politik, birokrasi tidak boleh netral. la harus meningkatkan intensitas keterlibatannya dalam proses politik. Tetapi, keterlibatan birokrasi publik itu tidak hanya diorientasikan untuk mengejar keuntungan kelompok semata-mata. Keterlibatan birokrasi dalam proses politik dan ketidaknetralan birokrasi adalah keberpihakan birokrasi terhadap kepentingan publik seperti kemajuan ekonomi, keadilan sosial, hak asasi manusia, kesetaraan gender, dan sebagainya. Dalam mewujudkan Hubungan Industrial Pancasila sebagaimana yang telah dikemukakan di atas tidak terlepas dari hubungan birokrasi dan politik dalam suatu bangsa, oleh karena itu, penting dilakukan Reinventing Hubungan Birokrasi dan Politik dalam mewujudkan demokratisasi hubungan industrial yang berkeadilan sesuai dengan nilai-nilai pancasila itu sendiri yaitu dengan melakukan Tata Kepemerintahan yang baik (Good Governance). Konsep ini lahir sejalan dengan konsep-konsep dan terminologi demokrasi, masyarakat sipil, partisipasi rakyat, hak asasi manusia, dan pembangunan masyarakat secara berkelanjutan.

\section{Daftar Pustaka}

Ali Abdul Wakhid, 2012, Hubungan Pemerintah Dan Birokrasi, Jurnal TAPIs Vol.8 No.2

Ari Hernawan, 2011, Hukum dan Kekuasaan Dalam Hubungan Industrial, Mimbar Hukum Edisi Khusus

Doyle Paul Johnson, 1994, Teori Sosiologi Klasik dan Modern, Gramedia Pustaka Utama, Jakarta. 1994

Dwight Waldo, 1948, The Administrative State : A. Study Of The Political Theory Of American Public Administration; New York; The Ronald Press

Eman Hermawan, 2002, Politik Membela yang Benar Teori Kritik dan Nalar, KLIK-DKN Garda Bangsa, Yogyakarta.

E. Utrecht, 1966, Pengantar Dalam Hukum Indonesia, Ichtiar, Jakarta.

E. Norton Long, 1966, Power Administration Dalam Francis E. Rourke; Bureaucratic; power In National Policy Making; Boston Company.

Fritje Rumimpunu, 2014, Sistem Hubungan Industrial Pancasila di Indonesia dengan Tenaga Kerja, Perusahaan di Lihat dari Aspek Undang-Undang Tenaga Kerja Nomor 13 Tahun 2003. Jurnal Hukum Unsrat Vol. II/No.02/Januari-Maret/2014. Edisi Khusus repo,unsrat.ac.id.

Frederick,S. Long, 1984, Current Issues In Public Administration; New York; Martin Pres.

Frederick C. Mosher, 1975, Some Notes on Reorganization in Public Agencies.

Hari Yanto, 1991, Elit, Massa dan Konflik, PAU Studi Sosial dan Gajah Mada University Press, Yogyakarta.

Leonard D White, 1926, Introduction to the Study of Public Administration.

Louis Kreisberg, 1982, Social Conflicts, Prentice Hall. Englewood Cliffs.

Miftah Toha, 2014, Birokrasi dan Politik di Indonesia, Rajawali Press, Jakarta.

Martin, Roscoe C., 2002, (eds.), Public Administration and Democracy: Essays in honor of Paul Appleby. New York, St. Martin Press. Asian Development Bank,

Max Weber, 1947, Theory Of Sosial and Economic Organization, Trans. By. A.M. Henderson And Talcott Parson, Oxford University Press, New York. NY.

Rafael Raga Manan, 2001, Pengantar Sosiologi Politik, Rineka Cipta, Jakarta.

Woodrow, Wilson, 1887, The Study of Administration, dalam Shafritz, Jay M., dan Hyde. 